\title{
Renal and neurological side effects of colistin in critically ill patients
}

\author{
Herbert Spapen", Rita Jacobs, Viola Van Gorp, Joris Troubleyn and Patrick M Honoré
}

\begin{abstract}
Colistin is a complex polypeptide antibiotic composed mainly of colistin A and B. It was abandoned from clinical use in the 1970s because of significant renal and, to a lesser extent, neurological toxicity. Actually, colistin is increasingly put forward as salvage or even first-line treatment for severe multidrug-resistant, Gram-negative bacterial infections, particularly in the intensive care setting. We reviewed the most recent literature on colistin treatment, focusing on efficacy and toxicity issues. The method used for literature search was based on a PubMed retrieval using very precise criteria.

Despite large variations in dose and duration, colistin treatment produces relatively high clinical cure rates. Colistin is potentially nephrotoxic but currently used criteria tend to overestimate the incidence of kidney injury.

Nephrotoxicity independently predicts fewer cures of infection and increased mortality. Total cumulative colistin dose is associated with kidney damage, suggesting that shortening of treatment duration could decrease the incidence of nephrotoxicity. Factors that may enhance colistin nephrotoxicity (i.e., shock, hypoalbuminemia, concomitant use of potentially nephrotoxic drugs) must be combated or controlled. Neurotoxicity does not seem to be a major issue during colistin treatment. A better knowledge of colistin pharmacokinetics in critically ill patients is imperative for obtaining colistin dosing regimens that ensure maximal antibacterial activity at minimal toxicity.
\end{abstract}

\section{Introduction}

Colistin belongs to the polymyxin class of cationic polypeptide antibiotics. It is administered as the prodrug colistimethate sodium (CMS), a fraction of which is hydrolyzed in vivo to colistin. During the 1970s, the popularity of colistin rapidly faded because of reports of significant renal and neurological toxicity and it was progressively supplanted by less toxic antibiotics with a comparable or broader antibacterial spectrum. However, the mounting prevalence worldwide of infections due to multidrug-resistant (MDR) Gram-negative bacilli has renewed interest into colistin but also revived the discussion about its toxicity [1].

We searched the PubMed database for English language studies (a) published during the last 15 years (from January 1995 to December 2010); (b) including at least 10 critically ill adult patients without cystic fibrosis treated with intravenous CMS as primary or salvage therapy for MDR Gram-negative organisms; and (c)

\footnotetext{
* Correspondence: herbert.spapen@uzbrussel.be Intensive Care Department, University Hospital, Vrije Universiteit Brussel, Laarbeeklaan 101, B-1090 Brussels, Belgium
}

reporting data on efficacy, nephrotoxicity, and neurotoxicity. A total of 26 relevant studies [2-27] were identified and are summarized in Table 1.

\section{Patient characteristics}

The majority of patients were hospitalized in general or specialized intensive care units (ICU). Patients were mainly treated for pulmonary, catheter-related or primary bloodstream, urinary tract, (surgical) wound, and abdominal and central nervous system infections. The most frequently isolated pathogens were MDR Acinetobacter baumannii and Pseudomonas aeruginosa. Some overlap between studies is present. Kallel et al. evaluated CMS treatment in a wide array of infections [10] but also more specifically discussed a subgroup of patients with ventilator-associated pneumonia [14]. The large cohort study by Falagas et al. [25] included data on 108 patients, which were reported in previous studies from the same group $[5,7,16]$. Severity of illness, as determined by the APACHE II score, was very different between studies, which underline the individual impact

\section{SpringerOpen ${ }^{\circ}$}

(c) 2011 Spapen et al; licensee Springer. This is an Open Access article distributed under the terms of the Creative Commons Attribution License (http://creativecommons.org/licenses/by/2.0), which permits unrestricted use, distribution, and reproduction in any medium, provided the original work is properly cited. 
Table 1 Dosage, duration, outcome, and toxicity of intravenous colistimethate sodium in critically ill patients

\begin{tabular}{|c|c|c|c|c|c|c|}
\hline Author & Patients (N) & $\begin{array}{l}\text { APACHE II (mean } \\
\pm \text { SD) }\end{array}$ & $\begin{array}{l}\text { CMS dose/duration [mean } \pm \text { SD or } \\
\text { median (range)] }\end{array}$ & $\begin{array}{l}\text { Clinical cure } \\
\mathrm{N}(\%)\end{array}$ & $\begin{array}{l}\text { Nephrotoxicity } \\
\mathrm{N}(\%)\end{array}$ & Neurotoxicity \\
\hline Levin & $\begin{array}{l}59 \text { ( } 60 \\
\text { infections) }\end{array}$ & $13.1 \pm 7$ & $\begin{array}{l}152.8 \mathrm{mg} \pm 62.8 \mathrm{mg} \\
12.6 \pm 6.8 \text { days }\end{array}$ & $35(58.3)$ & $22(37)$ & none \\
\hline Markou & $\begin{array}{l}24 \text { ( } 26 \\
\text { infections) }\end{array}$ & 20.6 (mean) & $\begin{array}{l}3 \text { MIUq8h } \\
13.5 \text { days ( } 4-24 \text { days) }\end{array}$ & $17(65.4)$ & $3(14.5)$ & none \\
\hline $\begin{array}{l}\text { Garnacho- } \\
\text { Montero }\end{array}$ & 21 & $19.6 \pm 7.2$ & $\begin{array}{l}2.5 \mathrm{mg}-5 \mathrm{mg} / \mathrm{kg} / \text { day } \\
14.7 \pm 4.1 \text { days }\end{array}$ & $12(57.1)$ & $5(24)$ & none \\
\hline Michalopoulos & 43 & $25.8 \pm 7.7$ & $\begin{array}{l}3 \mathrm{MIUq} 8 \mathrm{~h} \\
18.6 \pm 5.8 \text { days }\end{array}$ & $32(74)$ & $8(18.6)$ & none \\
\hline Falagas & $\begin{array}{l}17 \text { ( } 19 \\
\text { infections) }\end{array}$ & $\begin{array}{l}14 \text { (median) } \\
43.4 \pm 14.6 \text { days }\end{array}$ & $4.4 \mathrm{MIU} \pm 2.1 \mathrm{MIU}$ & $14(74)$ & $1(5.2)$ & 1 \\
\hline Kasiakou & $\begin{array}{l}50 \text { (54 } \\
\text { infections) }\end{array}$ & $16.1 \pm 6.1$ & $\begin{array}{l}4.5 \mathrm{MIU} \pm 2.3 \mathrm{MIU} \\
21.3 \pm 16 \text { days }\end{array}$ & $36(66.7)$ & $4(8)$ & $1^{\mathrm{a}}$ \\
\hline Reina & 55 & $21 \pm 7$ & $\begin{array}{l}5 \mathrm{mg} / \mathrm{kg}(\max 300 \mathrm{mg} / \text { day }) \\
13 \pm 5 \text { days }\end{array}$ & NA & $0(0)$ & none \\
\hline Petrosillo ${ }^{\mathbf{b}}$ & 14 & NA & $\begin{array}{l}2 \text { MIUq8h } \\
12 \text { days (mean) }\end{array}$ & $9(64)$ & $1(7.1)$ & none \\
\hline Kallel & $\begin{array}{l}75 \text { ( } 78 \\
\text { infections) }\end{array}$ & $\begin{array}{l}\text { NA (SAPS || } 37 \pm \\
14)\end{array}$ & & $\begin{array}{l}5.5 \mathrm{MIU} \pm 1.1 \\
\mathrm{MIU} \\
9.3 \pm 3.8 \text { days }\end{array}$ & $\begin{array}{l}60(76.9) 7 / 52 \\
(13.5)\end{array}$ & 1 \\
\hline Koomanachai & 78 & 21.9 (mean) & $\begin{array}{l}179.6 \mathrm{mg} / \text { day (mean) } \\
11.9 \text { days (mean) }\end{array}$ & $63(80.8)$ & $24(30.8)$ & none \\
\hline Betrosian & 15 & $14 \pm 2$ & $\begin{array}{l}5.83 \mathrm{MIU} \pm 2.3 \mathrm{MIU} \\
\text { duration NA }\end{array}$ & $9(60)$ & $5(33)$ & none \\
\hline Bassetti $^{\mathbf{b}}$ & 29 & $17 \pm 3.7$ & $\begin{array}{l}2 \mathrm{MIUq} 8 \mathrm{~h} \\
17.7 \pm 10.4 \text { days }\end{array}$ & $22(76)$ & $3(10)$ & none \\
\hline Kallel & 60 & $\begin{array}{l}\text { NA (SAPS \| } 35 \pm \\
12)\end{array}$ & $\begin{array}{l}2 \mathrm{MIUq} 8 \mathrm{~h} \\
9.5 \pm 3.8 \text { days }\end{array}$ & $45(75)$ & $0(0)$ & NA \\
\hline Falagas & 21 & $19 \pm 4$ & $\begin{array}{l}5.5 \mathrm{MIU} \pm 1.9 \mathrm{MIU} \\
17.7 \pm 11.7 \text { days }\end{array}$ & $11(52.4)$ & $3(14.3)$ & none \\
\hline \multirow[t]{2}{*}{ Falagas } & $\begin{array}{l}14 \text { (CMS } \\
\text { mono) }\end{array}$ & $14.3 \pm 7.4$ & $\begin{array}{l}4.6 \mathrm{MIU} \pm 2.3 \mathrm{MIU} \\
14.2 \pm 7.3 \text { days }\end{array}$ & $12(85.7)$ & $0(0)$ & NA \\
\hline & $\begin{array}{l}57(C M S \\
+M E R O)\end{array}$ & $15.4 \pm 6.6$ & $\begin{array}{l}5.5 \mathrm{MIU} \pm 2.2 \mathrm{MIU} \\
17.8 \pm 11.4 \text { days }\end{array}$ & $39(68.4)$ & $4(7)$ & NA \\
\hline Pintado & 60 & $11.2 \pm 7.7$ & $\begin{array}{l}4.42 \mathrm{MIU} \pm 1.39 \mathrm{MIU} \\
20 \pm 9.2 \text { days }\end{array}$ & $43(71.7)$ & 6/55 (10.9) & none \\
\hline Sabuda & 12 & NA & $\begin{array}{l}3.7 \mathrm{mg} / \mathrm{kg} \\
14.7 \pm 13.8 \text { days }\end{array}$ & $8(66.7)$ & $5(41.6)$ & 4 cases \\
\hline Huang & 15 & $14.7 \pm 4.5$ & $\begin{array}{l}1.28 \mathrm{MIU} \pm 0.25 \mathrm{MIU} \\
22.3 \pm 6.2 \text { days }\end{array}$ & $11(73.3)$ & $0(0)$ & none \\
\hline Hartzell & 66 & $8.3 \pm 6.5$ & $\begin{array}{l}4.3 \pm 1.2 \mathrm{mg} / \mathrm{kg} / \mathrm{day} \\
15.8 \pm 9.2 \mathrm{days}\end{array}$ & NA & $30(45)$ & 2 cases \\
\hline Kim & $\begin{array}{l}42 \text { ( } 47 \\
\text { infections) }\end{array}$ & NA & $\begin{array}{l}2.25 \mathrm{~g}(0.6-8.7 \mathrm{~g})^{\mathbf{c}} \\
16.6 \pm 14.8 \text { days }^{\mathrm{e}}\end{array}$ & $10 / 15(66)^{d}$ & $15(31.9)$ & none \\
\hline Kwon & 71 & NA & $\begin{array}{l}4.6 \mathrm{mg} / \mathrm{kg} \text { (median) } \\
13 \text { days (7-22 days) }\end{array}$ & NA & $38(53.5)$ & none \\
\hline Cheng & $115^{\mathbf{f}}$ & 6 (median) & $\begin{array}{l}\text { dose NA } \\
12 \pm 7 \text { days }\end{array}$ & $59(51)$ & $12 / 84(14)$ & 4 cases \\
\hline Song & 10 & NA & $\begin{array}{l}150 \mathrm{mg} \mathrm{q} 12 \mathrm{~h} \\
8.1 \pm 1.8 \text { days }\end{array}$ & $7(70)$ & $0(0)$ & none \\
\hline Falagas $^{\mathbf{h}}$ & 258 & 17 (range 2-39) & $\begin{array}{l}\text { up to } 3 \text { MIUq8h } \\
\text { mean } 17.9 \text { days (10-22) }\end{array}$ & $204(79.1)$ & $26(10)$ & NA \\
\hline Kofteridis & 43 & $17.7 \pm 7.6$ & $\begin{array}{l}3 \text { MIUq8h } \\
\text { median } 10 \text { days ( } 4-36 \text { days) }\end{array}$ & $14(32.5)$ & $8(19)$ & none \\
\hline DeRyke & 30 & 13 (range $7-18)^{\mathbf{i}}$ & $\begin{array}{l}5.1 \pm 2 \mathrm{mg} / \mathrm{kg} / \mathrm{day}^{\mathrm{j}} \\
\text { median } 8 \text { days }(3-24)\end{array}$ & NA & $10(33 \%)$ & none \\
\hline
\end{tabular}

NA = not available; APACHE II = Acute Physiology and Chronic Health Evaluation II score; SAPS 2 = Simplified Acute Physiology Score 2; MIU = million International Units; CMS = colistimethate sodium; MERO = meropenem.

${ }^{a}$ Same patient as in reference $6 ;{ }^{b}+$ rifampicine; ${ }^{c}$ mean cumulative CMS dose when nephrotoxicity occurred; ${ }^{d}$ in patients presenting nephrotoxicity; ${ }^{e}$ in patients presenting nephrotoxicity (vs. $9.5 \pm 5.6$ days in patients without nephrotoxicity, $p=0.07$ ); ${ }_{31}$ patients on renal replacement therapy at start of CMS treatment;

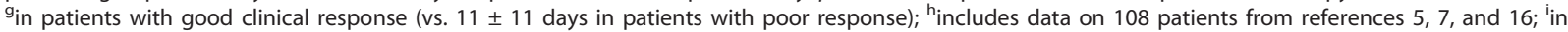
patients who developed nephrotoxicity; ${ }^{j}$ based on ideal body weight. 
of score-determining factors, such as age, pre-existing renal dysfunction, shock, and respiratory failure.

\section{Dose, duration, and efficacy of colistimethate sodium treatment}

CMS was mostly administered for 10 to 14 days. Dose regimens varied considerably and were kept constant daily over time or adapted to the patients' weight. Doses were adjusted for renal function depending on serum creatinine levels or creatinine clearance. CMS was used as monotherapy, in association with synergistic antibiotics (e.g. rifampicin) or in combination with other broad-spectrum antimicrobials. Clinical efficacy and toxicity of CMS were evaluated regardless of whether CMS was prescribed as monotherapy or in combination with other agents. Global clinical cure for all infections taken together in all evaluable patients approached $70 \%$.

The largest single-center cohort study to date retrospectively investigated 258 patients with microbiologically documented infection [25]. Patients were treated for at least $72 \mathrm{~h}$ with intravenous CMS, either alone or in combination with other antibiotics, and were evaluated during a 7-year period (2000-2007). Because few patients developed significant nephrotoxicity, the investigators progressively increased daily CMS doses over time, reaching a standardized protocol of 9 million IU per day (in 3 divided doses) during the last 2 years of the study. CMS dose was always adapted to renal function. Infection was cured in $79.1 \%$ of patients. Independent factors for a favorable infection outcome were antimicrobial regimens that consisted of CMS in monotherapy or in combination with meropenem (compared with CMS combined with other agents with potential activity against the isolated pathogen) and pneumonia (compared with bacteremia and abdominal infection), whereas age and proportional increase in creatinine independently predicted unfavorable infection outcome. Lower mean colistin daily dose (3 million IU compared with 6 and 9 million IU), APACHE II score, hematological disease, and nephrotoxicity were independent factors predicting increased mortality.

\section{Nephrotoxicity}

Renal toxicity is the most common adverse effect of colistin treatment because the drug is excreted primarily by the kidneys and elevated blood levels may further impair renal function. Little information is available on the mechanism of toxicity but in vitro electrophysiological studies demonstrate that, at long exposure times, colistin is directly toxic to mammalian urothelium by increasing transepithelial conduction [28].

A disparity between old and recent studies exists in the reported rates of nephrotoxicity associated with intravenous administration of colistin [29]. The recent studies generally indicate a relatively lower incidence of renal toxicity. This can be explained by the use of more purified colistin, the use of colistimethate instead of colistin sulphate, more adequate dose adjustment according to renal function and significant improvement of ICU monitoring (in particular of the patient's hydration status) and treatment (more rapid and adequate resuscitation of severe sepsis and shock and avoidance of concomitant administration of potentially nephrotoxic agents).

Nephrotoxicity rates vary widely, ranging between $0 \%$ and $53.5 \%$ [2-27], but comparison between studies is hazardous and complicated by a lack of control for risk factors and a case mix of patients with and without renal dysfunction at baseline. Moreover, the wide range of reported nephrotoxicity rates probably reflects more the varying definitions of "renal failure" than the actual effect of colistin. In studies that discriminate between patients with normal and impaired renal function before start of colistin treatment, the incidence of nephrotoxicity was 2.5- to 7-fold higher in patients with baseline renal dysfunction [2,5,7]. Koomanachai et al. reported a $30.8 \%$ incidence of nephrotoxicity [11]. However, $70 \%$ of their patients had underlying or predisposing factors (chronic kidney disease, nephrotoxic drug use, hypovolemia), which might have contributed to a decline in renal function. Also, $58 \%$ of the patients were not treated in an ICU environment despite a high mean APACHE II score for the whole group. Nephrotoxic effects were mild and reversible, and no patient required renal replacement therapy. A Canadian study reported at least a doubling of serum creatinine in 5 of 12 patients (41.6\%) treated with intravenous CMS for at least 3 days [18]. Once again, these patients had severe underlying diseases and comorbidities and all but one received at least one other potentially nephrotoxic drug. The only patient with renal failure admitted to the ICU even had received the equivalent of 13 million IU of colistin per day. It is noteworthy that the effectiveness and nephrotoxic potential of intravenous CMS was not different from imipenem in two studies comparing both antibiotics in the treatment of ventilator-associated pneumonia $[4,14]$.

Three recent studies used the RIFLE (Risk - Injury Failure - Loss - End stage renal disease) classification to determine CMS-associated nephrotoxicity [20,22,27]. The RIFLE criteria (Table 2) represent an extensively validated tool for evaluation of acute kidney injury, ranging from mild renal dysfunction to need for renal replacement therapy $[30,31]$. Hartzell et al. retrospectively reviewed 66 young adult patients who received intravenous CMS for at least 3 days [20]. Overall, 30 (45\%) patients exhibited criteria for nephrotoxicity at the time of peak creatinine level (Risk: 13 patients; Injury: 10 patients; Failure: 7 patients). In $21 \%$ of the patients, CMS was stopped because of nephrotoxicity. 
Table 2 RIFLE classification (serum creatinine and GFR criteria)

\begin{tabular}{ll}
\hline Category & Criteria \\
\hline Risk $(\mathbf{R})$ & Increased creatinine level $\times 1.5$ or GFR decrease $>25 \%$ \\
\hline Injury $(\mathbf{I})$ & Increased creatinine level $\times 2$ or GFR decrease $>50 \%$ \\
\hline Failure $(\mathbf{F})$ & Increased creatinine level $\times 3$, GFR decrease $>75 \%$ or creatinine level $>4 \mathrm{mg} / \mathrm{dL}$ \\
\hline Loss $(\mathbf{L})$ & Persistent acute renal failure or complete loss of function for $>4$ weeks \\
\hline ESKD $(\mathbf{E})$ & ESKD for $>3$ months \\
\hline
\end{tabular}

GFR = glomerular filtration rate; ESKD = end-stage kidney disease

No patient required renal replacement therapy. One month after the last CMS dose, criteria for Risk and Injury were still present in respectively 14 (28\%) and 1 (2\%) of 50 evaluable patients. In accordance with other studies $[15,27,32,33]$, kidney injury was found to be related to the total cumulative dose and the duration of CMS therapy. Kwon et al. determined the incidence of CMS-associated kidney injury in 71 adult patients receiving CMS for more than 3 days [22]. Thirty-eight (53.5\%) patients experienced nephrotoxicity (Risk: 11 patients; Injury: 10 patients; Failure: 17 patients). Compared with the study of Hartzell et al. [20], these patients were older, more severely ill, and also had chronic kidney disease or comorbidities predisposing them to renal toxicity. Cumulative dose of CMS was lower, probably because the dosage was more frequently modified for renal impairment. After discontinuation of CMS, renal function recovered completely in 16 (42\%) patients. Cox regression analysis based on the cumulative dose of CMS identified four independent factors predicting acute CMS-induced kidney injury: male sex, concomitant use of a calcineurin inhibitor, hyperbilirubinemia, and hypoalbuminemia. The incidence of kidney injury increased with an increase in the number of risk factors. Hypoalbuminemia also was identified as an independent risk factor for CMS-induced nephrotoxicity in another study [21]. It is hypothesized that high serum levels of free colistin might enhance renal toxicity in patients with low albumin levels. Hypoalbuminemia also may reflect the severity of the underlying illness. Finally, DeRyke et al. retrospectively studied 30 patients treated with CMS for at least $48 \mathrm{~h}$ [27]. Nephrotoxicity was observed in ten (33\%) patients (Injury: 3 patients; Failure: 5 patients; End-stage: 2 patients). Patients who developed nephrotoxicity were older, had more shock, and received excessive daily doses of colistin.

All studies using the RIFLE criteria reported a considerably higher incidence of CMS-induced nephrotoxicity $[20,22,27]$. A possible explanation may be the very high sensitivity of the RIFLE criteria, identifying acute kidney injury at creatinine values that are largely below the critical levels used to define renal failure (mostly above 1.3 to $2 \mathrm{mg} / \mathrm{dL}$ ) in the other studies. However, it is striking that the studies reporting the highest incidence of colistin-associated nephrotoxicity [18,20,22,27] used products containing $150 \mathrm{mg}$ of "colistin base activity." This has important implications for therapeutic dosing because $150 \mathrm{mg}$ of colistin base corresponds with approximately $400 \mathrm{mg}$ (or 5 million IU) of CMS. Given that many patients included in these studies had some degree of renal dysfunction at baseline or were treated for prolonged periods of time, it is possible that the observed nephrotoxicity was caused by "overdosing" with CMS. This is particularly obvious in the study of DeRyke et al. [27] where dose calculations based on actual body weight resulted in daily CMS doses of up to 25 million IU in some patients!

In summary, CMS has nephrotoxic effects but its potential to injure the kidney is probably overestimated particularly when very sensitive criteria (i.e., the RIFLE classification) are used. CMS-induced nephrotoxicity is mostly mild and reversible. Renal replacement therapy is occasionally required and permanent kidney damage is rarely seen. Still, deteriorating renal function remains an independent factor predicting treatment failure and increased mortality. Factors that may potentiate renal toxicity in an ICU setting, such as concomitant nephrotoxic medication, sepsis, shock, and hypoalbuminemia, should be adequately controlled. Rigorous application of recently highlighted measures designed to prevent kidney injury and to protect renal function in an ICU population remains warranted [34]. The observed association between total cumulative colistin dose and kidney damage suggests that shortening the duration of treatment for specific infections (e.g., pneumonia) could decrease the incidence of nephrotoxicity. It must be emphasized that dosage and frequency of colistin administration must be adjusted for serum creatinine levels and thus require close monitoring of renal function. Finally, the decision to stop colistin treatment on the basis of renal dysfunction must be weighed against the consequences of withholding a potentially life-saving antibiotic.

\section{Neurotoxicity}

The interaction of colistin with neurons, which have high lipid content, has been associated with the occurrence of peripheral and orofacial paresthesias, visual 
disturbances, vertigo, mental confusion, ataxia, and seizures [32]. The most dreaded neurotoxic event, however, is neuromuscular blockade presenting as a myasthenia-like syndrome or as respiratory muscle paralysis producing apnea $[35,36]$. Potential triggers of neurotoxicity are hypoxia, concomitant medication (muscle relaxants, narcotics, sedatives, anesthetic drugs, and corticosteroids) and impaired renal function. The incidence of colistin-associated neurotoxicity reported in the literature before 1975 was approximately 7\%, with paresthesias constituting the main event. Only sporadic cases of apnea were reported, typically in patients receiving colistin intramuscularly, suffering acute or chronic renal failure or treated with medications known to potentially induce respiratory muscle weakness [29]. More recent studies-all retrospective in design-did not observe a clear association between colistin treatment and neurotoxic events. Falagas et al. described four patients who had polymyoneuropathy during colistin treatment [6]. However, three patients already had neurological symptoms before colistin was started and in the one remaining patient, polyneuropathic symptoms subsided despite colistin was continued for 11 more days. Sabuda et al. reported four patients with varying neurological complaints [18]. All had developed significant renal dysfunction during treatment. Two patients had concomitant neurotoxic medication (gabapentin, baclofen, and tizanidine) or disorders (multifocal acute encephalopathy) that might have contributed to their neurological "distress" (respectively somnolence and vertigo). One patient with respiratory muscle weakness had received the equivalent of 13 million IU of colistin base per day for 19 days whilst experiencing a doubling of plasma creatinine levels. In a cohort of 115 patients, Cheng et al. identified four cases of potential colistininduced neurotoxicity, including three patients with focal seizures and one patient with altered mentation [23]. These patients had normal kidney function but details about concomitant treatment or comorbidities were not given.

Diagnosis of neurotoxicity is mostly made on clinical grounds, making it difficult to discriminate between eventual colistin-induced neurotoxicity and the more frequently observed "critical illness polymyoneuropathy" in ICU patients. In only one study, electrophysiological measurement was performed in a limited number of patients who had received colistin for at least 7 days. Among these patients, 50\% exhibited typical features consistent with critical illness polymyoneuropathy, but none had evidence of neuromuscular junction blockade [4]. Of note, no cases of clinically significant neurotoxicity were observed in a large group of patients with underlying neurological disease or disorders admitted to a neurosurgical ICU [11]. Finally, neuromuscular blockade was never seen in prospective studies evaluating CMS treatment $[2-4,8,12,13,15]$.

\section{Optimization of colistin therapy in critical illness}

The paucity of pharmacologic information regarding colistin administration in the critically ill highly impedes the creation of optimal dosing regimens that reconcile adequate antibacterial activity with minimal toxicity. Colistin pharmacokinetics are expected to be dramatically altered in critically ill patients, because they are frequently prone to large swings in distribution volume, fluctuations in renal clearance, and variable protein binding. Also, the antibacterial activity of colistin is attenuated in the face of high bacterial loads, as may be seen in pneumonia [37].

Data on colistin pharmacokinetics in critically ill patients with pneumonia and/or sepsis obtained by specific chromatographic assays became recently available [38-40]. The administration of CMS at a dose of 2 million IU [40] or 3 million IU [38,39] every 8 h resulted in maximum mean steady-state concentrations $\left(\mathrm{C}_{\max }\right)$ of colistin between 2.21 and $2.93 \mu \mathrm{g} / \mathrm{mL}$. These findings are troublesome, because they indicate that currently prescribed CMS doses may be inadequate for treatment of infections caused by pathogens with minimal inhibitory concentration values in the upper range of the susceptibility breakpoint for colistin $(2 \mu \mathrm{g} / \mathrm{mL})$ and could induce the selection of resistant strains. Whether this has an impact on clinical cure and/or outcome is not clear. From the study by Plachouras et al. [39], it is obvious that it takes 2 to 3 days to reach the $C_{\max }$ of colistin. These authors speculate that a loading dose of 9 to 12 million IU of CMS, followed by a maintenance dose of 4.5 million IU every $12 \mathrm{~h}$ would achieve the target $C_{\max }$ faster with less frequent administration. It remains to be investigated whether this will lead to improved treatment efficacy without raising concern about toxicity. Moreover, a recent in vitro pharmacodynamic study in a Pseudomonas aeruginosa model showed that dosing regimens incorporating higher doses of colistin administered less frequently produced similar bacterial killing at the cost of a greater emergence of resistance than the conventional thrice-daily regimen [41].

\section{Conclusions}

CMS is mostly prescribed for treatment of MDR Acinetobacter baumannii and Pseudomonas aeruginosa. Clinical cure rates are relatively high, especially when administered as monotherapy or in combination with a carbapenem. The dose varies considerably between studies but has become standardized over time to 9 million IU per day in patients with normal renal function.

CMS is potentially nephrotoxic but the incidence of kidney injury is probably overestimated by currently 
used criteria (e.g., the RIFLE classification) and may be influenced by manufacturer-dependent differences in dose recommendations. Although mostly mild and reversible, a decrease in kidney function must not be neglected, because it aggravates prognosis. The use of sensitive criteria to detect kidney injury could prove beneficial, because they may prompt clinicians to adequately address disease states, metabolic disorders, and medications that may enhance or precipitate colistin nephrotoxicity as well as encourage them to adapt CMS dosage or treatment duration in a timely manner.

Neurotoxicity does not seem to be a major adverse event accompanying colistin treatment. However, further studies must determine whether and how colistin interferes with underlying or ICU-acquired neurological disease (e.g., epilepsy, septic encephalopathy, critical illness polymyoneuropathy).

More research on colistin pharmacokinetics and pharmacodynamics in critically ill patients is urgently needed to guide adequate colistin dosing at the least toxicity.

\section{Authors' contributions}

HS and RJ conceived and wrote the review. WG and JT participated in literature search and selected appropriate articles. PMH participated in design, coordination, and writing. All authors read and approved the final manuscript.

\section{Competing interests}

The authors declare that they have no competing interests.

Received: 8 April 2011 Accepted: 25 May 2011 Published: 25 May 2011

\section{References}

1. Li J, Nation Rl, Turnidge JD, Milne RW, Coulthard K, Rayner CR, Paterson DL: Colistin: the re-emerging antibiotic for multidrug-resistant Gramnegative bacterial infections. Lancet Infect Dis 2006, 6:589-601.

2. Levin AS, Barone AA, Penço J, Santos MV, Marinho IS, Arruda EAG, Manrique El, Costa SF: Intravenous colistin as therapy for nosocomial infections caused by multidrug-resistant Pseudomonas aeruginosa and Acinetobacter baumannii. Clin Infect Dis 1999, 28:1008-1011.

3. Markou N, Apostolakos H, Koumoudiou C, Athanasiou M, Koutsoukou A Alamanos I, Gregorakos L: Intravenous colistin in the treatment of sepsis from multiresistant Gram-negative bacilli in critically ill patients. Crit Care 2003, 7:R78-R83.

4. Garnacho-Montero J, Ortiz-Leyba C, Jiménez-Jiménez J, BarreroAlmodovar AE, Garcia-Garmendia JL, Bernabeu-Wittell M, Gallego-Lara SL, Madrazo-Osuna J: Treatment of multidrug-resistant Acinetobacter baumannii ventilator-associated pneumonia (VAP) with intravenous colistin: a comparison with imipenem-susceptible VAP. Clin Infect Dis 2003, 36:1111-1118.

5. Michaloupoulos AS, Tsiodras S, Rellos K, Mentzelopoulos S, Falagas ME: Colistin treatment in patients with ICU-acquired infections caused by multiresistant Gram-negative bacteria: the renaissance of an old antibiotic. Clin Microbiol Infect 2005, 11:115-121.

6. Falagas ME, Rizos M, Bliziotis IA, Rellos K, Kasiakou SK, Michalopoulos A: Toxicity after prolonged (more than four weeks) administration of intravenous colistin. BMC Infect Dis 2005, 5:1-8.

7. Kasiakou SK, Michalopoulos A, Soteriades ES, Samonis G, Sermaides GJ, Falagas ME: Combination therapy with intravenous colistin for management of infections due to multidrug-resistant Gram-negative bacteria in patients without cystic fibrosis. Antimicrob Agents Chemother 2005, 48:3136-3146.
8. Reina R, Estenssoro E, Saenz G, Canales HS, Gonzalvo R, Vidal G, Martins G, Das Neves A, Santander O, Ramos C: Safety and efficacy of colistin in Acinetobacter and Pseudomonas infections: a prospective cohort study. Intensive Care Med 2005, 31:1058-1065.

9. Petrosillo N, Chinello P, Proietti MF, Cecchini L, Masala M, Franchi C, Venditti M, Esposito S, Nicastri E: Combined colistin and rifampicin therapy for carbapenem-resistant Acinetobacter baumannii infections: clinical outcome and adverse events. Clin Microbiol Infect Dis 2005, 11:682-683.

10. Kallel H, Bahloul M, Hergafi L, Akrout M, Ketata W, Chelly H, Ben Hamida CB, Rekik N, Hammami A, Bouaziz M: Colistin as a salvage therapy for nosocomial infections caused by multidrug-resistant bacteria in the ICU. Int J Antimicrob Agents 2006, 28:366-369.

11. Koomanachai $P$, Tiengrim S, Kiratisin $P$, Thamlikitkul V: Efficacy and safety of colistin (colistimethate sodium) for therapy of infections caused by multidrug-resistant Pseudomonas aeruginosa and Acinetobacter baumannii in Siriraj Hospital, Bangkok, Thailand. Int J Infect Dis 2007, 11:402-406.

12. Betrosian AP, Frantzeskaki F, Xanthaki A, Douzinas EE: Efficacy and safety of high-dose ampicillin/sulbactam vs. colistin as monotherapy for the treatment of mutidrug resistant Acinetobacter baumannii ventilatorassociated pneumonia. J Infect 2008, 56:432-436.

13. Bassetti M, Repetto E, Righi E, Boni S, Diverio M, Molinari MP, Mussap M, Artioli S, Ansaldi F, Durando P, Orengo G, Bobbio Pallavicini F, Viscoli C: Colistin and rifampicin in the treatment of multidrug-resistant Acinetobacter baumannii infections. J Antimicrob Chemother 2008, 61:417-420.

14. Kallel H, Hergafi L, Bahloul M, Hakim A, Dammak H, Chelly H, Ben Hamida C, Chaari A, Rekik N, Bouaziz M: Safety and efficacy of colistin compared with imipenem in the treatment of ventilator-associated pneumonia: a matched case-control study. Intensive Care Med 2007, 33:1162-1167.

15. Falagas ME, Fragoulis KN, Kasiakou SK, Sermaides GJ, Michalopoulos A: Nephrotoxicity of intravenous colistin: a prospective evaluation. Int $J$ Antimicrob Agents 2005, 26:504-507.

16. Falagas ME, Rafailidis PI, Kasiakou SK, Hatzopoulou P, Michalopoulos A: Effectiveness and nephrotoxicity of colistin monotherapy vs. colistinmeropenem combination therapy for multidrug-resistant Gram-negative bacterial infections. Clin Microbiol Infect 2006, 12:1227-1230.

17. Pintado V, Garcia San Miguel L, Grill F, Mejia B, Cobo J, Fortun J, MartinDavila P, Moreno S: Intravenous colistin sulphomethate sodium for therapy of infections due to multidrug-resistant gram-negative bacteria. J Infect 2008, 56:185-190.

18. Sabuda DM, Laupland K, Pitout J, Dalton B, Rabin H, Louie T, Conly J: Utilization of colistin for treatment of multidrug-resistant Pseudomonas aeruginosa.. Can J Infect Dis Med Microbiol 2008, 19:413-418.

19. Huang J, Tang YQ, Sun JY: Intravenous colistin sulfate: A rarely used form of polymyxin E for the treatment of severe multidrug-resistant Gramnegative bacterial infections. Scand J Infect Dis 2010, 42:260-265.

20. Hartzell JD, Neff R, Ake J, Howard R, Olson S, Paolino K, Vishnepolsky M, Weintrob A, Wortmann G: Nephrotoxicity associated with intravenous colistin (colistimethate sodium) treatment at a tertiary care medical center. Clin Infect Dis 2009, 48:1724-1728.

21. Kim J, Lee $\mathrm{KH}$, Yoo S, Pai H: Clinical characteristics and risk factors of colistin-induced nephrotoxicity. Int J Antimicrob Agents 2009, 34:434-438.

22. Kwon JA, Lee JE, Huh W, Peck KR, Kim YG, Kim DJ, Oh HY: Predictors of acute kidney injury associated with intravenous colistin treatment. Int J Antimicrob Agents 2010, 35:473-477.

23. Cheng CY, Sheng WH, Wang JT, Chen YC, Chang SC: Safety and efficacy of intravenous colistin (colistin methanesulphonate) for severe multidrugresistant Gram-negative bacterial infections. Int J Antimicrob Agents 2010, 35:297-300.

24. Song JY, Lee J, Heo JY, Noh JY, Kim WJ, Cheong HJ: Colistin and rifampicin combination in the treatment of ventilator-associated pneumonia caused by carbapenem-resistant Acinetobacter baumannii. Int J Antimicrob Agents 2008, 32:281-283.

25. Falagas ME, Rafailidis PI, Ioannidou E, Alexiou VG, Matthaiou DK, Karageorgopoulos DE, Kapaskelis A, Nikita D, Michalopoulos A: Colistin therapy for microbiologically documented multidrug-resistant Gramnegative bacterial infections: a retrospective cohort study of 258 patients. Int J Antimicrob Agents 2010, 35:194-199. 
26. Kofteridis DP, Alexopoulou C, Valachis A, Maraki S, Dimopoulou D, Georgopoulos D, Samonis G: Aerosolized plus intravenous colistin versus intravenous colistin alone for the treatment of ventilator-associated pneumonia: a matched case-control study. Clin Infect Dis 2010, 51:1238-1244.

27. DeRyke CA, Crawford AJ, Uddin N, Wallace MR: Colistin dosing and nephrotoxicity in a large community teaching hospital. Antimicrob Agents Chemother 2010, 54:4503-4505.

28. Lewis JR, Lewis SA: Colistin interactions with the mammalian urothelium. Am J Physiol Cell Physiol 2004, 286:C913-C922.

29. Falagas ME, Kasiakou SK: Toxicity of polymyxins: a systematic review of the evidence from old and recent studies. Crit Care 2006, 10:R27.

30. Bellomo R, Ronco C, Kellum JA, Mehta RL, Palevsky P, Acute Dialysis Quality initiative workgroup: Acute renal failure - definition, outcome measures, animal models, fluid therapy and information technology needs: the Second International Consensus Conference of the Acute Dialysis Quality Initiative (ADQI) Group. Crit Care 2004, 8:R204-R212.

31. Cruz DN, Ricci Z, Ronco C: Clinical review: RIFLE and AKIN - time for reappraisal. Crit Care 2009, 13:211.

32. Koch-Weser J, Sidel WW, Federman EB, Kanarek P, Finer DC, Eaton AE: Adverse effects of sodium colistimethate. Manifestations and specific reaction rates during 317 courses of therapy. Ann Intern Med 1970, 72:857-868.

33. Rattanaumpawan $P$, Ungprasert $P$, Thamlikitkul $V$ : Risk factors for colistinassociated nephrotoxicity. J Infect 2011, 62:187-190.

34. Joannidis M, Druml W, Forni LG, Groeneveld AB, Honore PM, Oudemansvan Straaten HM, Ronco C, Schetz MR, Woittiez AJ, Critical Care Nephrology Working Group of the European Society of Intensive Care Medicine: Prevention of acute kidney injury and protection of renal function in the intensive care unit. Expert opinion of the Working Group for Nephrology, ESICM. Intensive Care Med 2010, 36:392-411.

35. Parisi AF, Kaplan MH: Apnea during treatment with sodium colistimethate. JAMA 1965, 194:298-299.

36. McQuillen MP, Cantor HA, O'Rourke JR: Myasthenic syndrome associated with antibiotics. Trans Am Neurol Assoc 1967, 92:163-167.

37. Bulitta JB, Yang JC, Yohonn L, Ly NS, Brown SV, D'Hondt RE, Jusko WJ, Forrest A, Tsuji BT: Attenuation of colistin bactericidal activity by high inoculum of Pseudomonas aeruginosa characterized by a new mechanism-based population pharmacodynamic model. Antimicrob Agents Chemother 2010, 54:2051-2062.

38. Markou N, Markantonis SL, Dimitrakis E, Panidis D, Boutzouka E, Karatzas S, Rafailidis P, Apostolakos H, Baltopoulos G: Colistin serum concentrations after intravenous administration in critically ill patients with serious multidrug-resistant, Gram-negative bacilli infections: a prospective, open-label, uncontrolled study. Clin Ther 2008, 30:143-151.

39. Plachouras D, Karvanen M, Friberg LE, Papadomichelakis E, Antoniadou A, Tsangaris I, Karaiskos I, Poulakou G, Kontopidou F, Armaganidis A, Cars O, Giamarellou H: Population pharmacokinetic analysis of colistin methanesulfonate and colistin after intravenous administration in critically ill patients with infections caused by Gram-negative bacteria. Antimicrob Agents Chemother 2009, 53:3430-3436.

40. Imberti R, Cusato M, Villani P, Carnevale L, lotti GA, Langer M, Regazzi M: Steady-state pharmacokinetics and BAL concentration of colistin in critically ill patients after iv colistin methanesulfonate administration. Chest 2010, 138:1333-1339.

41. Bergen PJ, Li J, Nation RL, Turnidge JD, Coulthard K, Milne RW: Comparison of once-, twice- and thrice-daily dosing of colistin on antibacterial effect and emergence of resistance: studies with Pseudomonas aeruginosa in an in vitro pharmacodynamic model. J Antimicrob Chemother 2008, 61:636-642.

doi:10.1186/2110-5820-1-14

Cite this article as: Spapen et al:: Renal and neurological side effects of colistin in critically ill patients. Annals of Intensive Care 2011 1:14.

\section{Submit your manuscript to a SpringerOpen ${ }^{\circ}$ journal and benefit from:}

- Convenient online submission

- Rigorous peer review

- Immediate publication on acceptance

- Open access: articles freely available online

- High visibility within the field

- Retaining the copyright to your article

Submit your next manuscript at $\gg$ springeropen.com 